\title{
10 Mining, Catholic social teaching, and international human rights
}

\author{
Douglass Cassel
}

Mining worldwide generates a diverse range of risks and harms to human rights, the environment, and peace. These arise from extraction, transport, waste, and mining revenues, and vary depending on what is mined, where, how, and the end uses. Mining may also yield offsetting benefits in employment, economic growth, and valuable end uses such as medical equipment and personal computers. Catholic social teaching and secular international human rights norms on mitigating harms and enhancing benefits have much in common and are generally compatible. Both focus on the impacts of mining on human dignity, the environment, and peace. However, they also diverge in fundamental ways.

As epitomized in Laudato Si', Catholic social teaching recognizes fundamental human rights and the need for international human rights laws and institutions (Francis 2015, $\$ 53,93,157,173,175$ ). But the concept of human rights in Catholic social teaching is much broader than in secular law. The church insists on an integral, holistic, communitarian, spiritually grounded vision of human development and peace. Concern for our planet unites with compassion for our sisters and brothers, especially the poor, in an inseparable whole. These lofty goals call for nothing less than a cultural "revolution" (\$114). Laudato Si' teaches that our societies, ecology, and personal well-being are all maimed by market-driven materialism, consumerism, overblown individualism, self-centered pursuit of immediate gratification, anthropocentrism, and a false faith that endless technological progress will forever yield unlimited economic growth. It sounds an urgent call that our earthly home is fast reaching the limits of its capacity to tolerate our cultural and material excesses.

Secular international human rights norms share important values with the Catholic faith, notably respect for human dignity and security. They take broader stands in support of liberty and against discrimination. But they do not aim as high as the church. Widely agreed international norms are necessarily the product of consensus diplomacy among nations, whose diverse political and value systems are immersed in a market-driven global culture of technological progress and material growth. Norms adopted by international organizations reflect both what is common and what is diverse among their member states.

DOI: $10.4324 / 9781003094272-10$ 


\section{Douglass Cassel}

The United Nations encompasses democratic as well as repressive states, and religious as well as secular cultures. The result is that international norms, far from upsetting political and economic apple-carts, tend toward the lowest common denominator. Rather than reach for the heavens, they erect a floor. You need not love your neighbor, but you must not torture her.

Unlike Catholic social teaching, international human rights norms emphasize rights over responsibilities. Lacking an agreed, unifying theory, international human rights reduce to a menu of separate rights, instead of a cohesive, integral whole (see Glendon 1998). While necessary to avert suffering, they do not aspire to maximize the common good. They do not challenge the sins of their authors: materialism, consumerism, self-centeredness, and the myth of endless growth. They accept cultures, however misguided, and development models, however short-sighted. The price of gaining widespread acceptance by governments is settling for minimum, albeit critically important, rules of civility.

Mining is not exempt from these profound differences between Catholic social teaching and international human rights norms. If Laudato $\mathrm{Si}^{\prime}$ is revolutionary, secular international norms for mining are merely regulatory. Coal mining is an example. Laudato Si' asserts the "use of highly polluting fossil fuels-especially coal...needs to be progressively replaced without delay" (Francis 2015, \$165). By contrast, international norms seek to curb the coal industry's pollution, require it to respect local communities, avoid repressive violence, not fuel armed conflict, and move gradually to reduce carbon emissions. Still, at present, they seek only to rein in, not challenge the very existence of, the industry.

This difference between Catholic social teaching and international human rights norms is illustrated more broadly by their contrasting attitudes toward the end uses and profits of mining. The church considers the intrinsic value of the end use of what is mined, based on its contribution to integral human development. By contrast, international human rights norms on mining pay no attention to the intrinsic value of the end use. International norms adopted by governments, not by theologians, accept market valuations of mining based on monetary worth in consumerist societies.

Consider gold mines. Even when operated by the cleanest modern techniques, they pollute. Some level of environmental cost could be justified if the gold is to be used for, say, life-saving medical technology. In fact, the vast majority of gold mined nowadays (other than for bullion) is destined for jewelry (Sepanek 2012). The church would ask, is self-adornment worth the environmental costs? International human rights norms do consider the environmental impacts of gold mining. But they pay no attention to the intrinsic value of the end use. Their environmental regulations are the same regardless of whether the gold will be used to save lives or to adorn people. Much less do they condition the right to mine gold for a profit on the end use.

Catholic social teaching and international human rights norms also differ on the pope's injunction to mining executives to balance profits against a need 
to "reduce, reuse, recycle" (Francis 2019). There may be no present need to mine more gold for jewelry. There may be so much of the mineral already in jewelry stores and pawn shops that we do not need to dig for more. Gold-mining executives might choke on this conclusion, and to suspend gold mining for jewelry would also affect the gainful employment of miners, cutters, and merchants. Still, on a holistic view, Catholic social teaching arguably calls on us, before we mine more, to sell what already gleams through countless shop windows around the globe. International human rights norms do not go so far. So long as reasonable environmental and human rights safeguards are followed, these secular norms do not object to a mining company digging for gold we do not need in order to sell it for a profit. If a company can make money by mining, that's fine. And if a country's government, aiming to expand its economy, markets itself as the gold mining capital of a world already up to its neck in baubles, that's fine, too.

Catholic social teaching, then, is vastly more ambitious than international human rights norms. Even so, its lofty aspirations may have much to learn from the specificity and practicality of evolving international human rights norms for business, in general, and mining, in particular. The United Nations Guiding Principles on Business and Human Rights reiterate the legal duties of states to protect human rights, including from business; confirm the social responsibility of business to respect human rights; and make clear the duty of states and responsibility of business to facilitate remedies when business activities adversely impact human rights (UN Office of the High Commissioner for Human Rights 2011). The Guiding Principles are now increasingly supplemented and implemented by other global and regional norms, national laws, and, as Ray Offenheiser outlines in his chapter in this volume, by industry codes and company policies and procedures. Soon after their adoption, the church wisely endorsed the Guiding Principles (Tomasi 2014). Much remains to be done, but the trend lines of secular norms are moving toward moderating the worst social and environmental excesses of the mining industry. Yet it is unrealistic to expect secular norms, however helpful, ever to embrace the revolution in values, culture, worldview, and models of development advocated by Laudato Si'.

The following sections address, first, the diversity of mining industries; second, the impacts of mining on human rights, the environment, and peace; third, teaching from Laudato Si' pertinent to mining issues; fourth, international human rights norms; fifth, international norms on peace; and finally, how Catholic teaching and international norms might be combined to better serve peace and the common good.

\section{Mining diversity}

Not all mining is the same; neither Catholic social teaching nor international norms can adopt a one-size-fits-all approach. Analysis of costs and 


\section{Douglass Cassel}

benefits must be disaggregated, and should consider the mining technologies used for different substances and varied end uses, ranging from frivolous to useful to critically important.

There is geographical diversity and endless variation in what is mined and end uses. China is by far the globe's champion miner. Not only is it the world's largest producer of coal and gold, China also has "great prospecting potential" for 22 other "major minerals," including iron ore, manganese, chromite, copper, lead, zinc, bauxite, tungsten, tin, molybdenum, antimony, nickel, silver, lithium, pyrites, sulphurite, phosphate rock, potash, magnesite, fluorite, boron and barite (Wu and $\mathrm{Li}$ 2018). In addition, China is the world's leading producer of "rare earth minerals" which are unknown to most of us, but are strategically or commercially important. Leading examples include lanthanum (used in hybrid vehicles and smart phones), cerium (used in catalytic converters and LED lighting), and terbium (used for solid state electronics, fuel cells, and naval sonar).

Latin American mining portfolios are likewise large and varied. Mexico, the world's largest miner of silver, is also an important producer of copper, coal, gold, zinc, and uranium, and a major producer of twelve minerals, three of which are important for U.S. demand: fluorspar (used in aluminum, gasoline, insulating foams, refrigerants, steel, and uranium fuel), graphite (for lubricants, electrodes, batteries, and solar panels), and strontium (for fireworks, flares, and glow-in-the-dark paints, among others) (UITA 2019b). Mining mixes differ elsewhere in Latin America. Chile leads the world in mining copper and is second in lithium (UITA 2021). Peru is Latin America's largest miner of gold and second largest of copper and silver (UITA 2020). Colombia leads the region in coal mining and has "great opportunities" for gold, copper, and nickel (Griffin and Acosta 2020). Important mining sectors in Bolivia include zinc, lead, tin, gold, silver, copper, and tungsten (UITA 2019a).

The foregoing merely gives a flavor of the diversity in what is mined, where, and for what end uses. The goal is not to present an exhaustive global portrait, but to illustrate differences that can affect how both Catholic social teaching and international norms assess mining industries.

\section{Mining's global and local impacts}

The social and environmental impacts of mining are both global (especially in end uses and through global warming) and local (the impacts on human rights, the environment, and peace in the community, country, and region where the mining takes place).

The most extensive global impacts at present arguably come from burning coal to fuel electric power plants and heat homes-a major source of carbon emissions and a major contributor to climate change. With substitute fuels increasingly available and competitive, thermal coal use globally appears to have peaked in 2013. Since then, use has fallen steeply 
in Europe and North America, and is projected to decline even further by 2025. However, in China, which already produces and consumes nearly half of all thermal coal worldwide, demand in 2025 is projected to be about the same as in 2019. Meanwhile, thermal coal use in India, and also in Southeast Asia, each of whose coal usage is already more than the United States and Europe combined, is projected to keep growing (International Energy Agency 2020). Other top revenue generators from mining-coking coal, iron ore, and copper-likewise contribute significantly to climate change (Greenpeace Australia Pacific 2017; Pooler 2019; Brown 2016).

Nuclear power is touted by some as a clean substitute for electricity generation by fossil fuels. But wholly aside from the significant risks of radioactive pollution from uranium mining, and the safety and environmental risks of operating nuclear power plants, global challenges of uranium mining include disposing of nuclear waste and ensuring that nuclear materials are used only for peaceful purposes, rather than for nuclear arms proliferation or for terrorism. ${ }^{1}$

In the communities and countries (and sometimes the regions) where mining takes place, the potential adverse impacts of mining on human rights, environment, and peace are many and varied. They may include discharge of toxic substances into air, water, and soil, harming not only human health, but the continued ability of local residents to farm, fish, earn a livelihood, and sustain their families. Vibrations and noise disturb tranquility and may crack walls and roofs of housing. Indigenous lands, sometimes including sacred places, are often encroached upon without free, prior, and informed consent. There may be little or no community consultation about mining projects. Importation of mineworkers may lead to prostitution and other social problems. Where land is taken for mining, forced or mass displacement may result. Traditional collective ownership of land may be disrespected for lack of formal titles, and legal (or corrupt) titles given or sold to mining companies. When mines close, ravaged hills and streams may not be restored, or communities may be left to pay the costs, or restoration may be impossible for decades because of acid drainage.

The economic impact on communities can also be significant. As Albino Barrera points out in his chapter, mining operations in the Global South rarely help the industry generate sustainable wealth in the host country, but instead allow for the formation of extractive-export enclaves. This pattern helps to keep the Global North enriched and the Global South impoverished, while the latter remains on the front lines in coping with climate change.

In many instances, these problems lead to resistance and protests by community members and their defenders. In countries where the rule of law is weak (as in much of the Global South), they may be arrested, jailed, prosecuted on false or trumped-up charges, threatened, harassed, tortured, or killed (see DeJusticia and Business and Human Rights Resource Centre 2015). And in nations beset by war, mining may become a major source of 


\section{Douglass Cassel}

funds to fuel armed conflict, such as "blood diamonds" in Sierra Leone (King n.d.) or coltan and "3TG" (tin, tantalum, tungsten and gold) in the Congo (Heath 2014).

\section{Examples of human rights cases against mining companies}

Colombia. The range of human rights issues that can arise at a single mine is illustrated by a recent complaint filed against three of the world's mining giants-BHP, Anglo American, and Glencore. Supported by several other human rights groups, the Global Legal Action Network (GLAN) filed a complaint against the three companies with the National Contact Points (NCPs) in Australia, Switzerland, and the UK (their home countries) in connection with their joint venture ownership of the El Cerrejón mine in Colombia. The complaint alleges "Non-Compliance with the OECD Guidelines for Multinational Enterprises" (GLAN 2021). El Cerrejón is one of the largest open-pit coal mines in the world. GLAN alleges that the mine has caused air and noise pollution and related health impacts, contamination of a river and nearby waterways, interference with the local hydrological system, food insecurity, and an adverse impact on climate change. GLAN further alleges that the three companies have inadequately responded to threats against activists and have displaced indigenous communities, damaged their cultural heritage, and undertaken other activities without their consent.

The complaint adds that the UN Special Rapporteur on Human Rights and the Environment declared El Cerrejón "one of the most disturbing situations" he had learned about (GLAN 2021, 2n3). At this writing, the NCPs have not yet reached conclusions concerning these allegations. Meanwhile, the jointly-owned company announced an agreement in February 2021 with the Wayúu community, by which it would resolve a Colombian court case, reportedly by building a community health center; carrying out an environmental rehabilitation program to include the planting of 250,000 trees; cleaning community facilities and nearby areas over the next five years; and providing technical support for measuring air quality (Reuters 2021). Nonetheless, Glencore has recently brought an international arbitration claim against Colombia over El Cerrejon, and the NCP complaints illustrate the issues of human rights, environment, and conflict that often arise at mines (Bnamericas 2021).

Guatemala. In 2013 a Superior Court of Ontario, Canada, denied a motion to dismiss three lawsuits brought by indigenous Mayans in Guatemala against Canada's HudBay Minerals. Community members had protested a proposed open-pit nickel mine. The Mayan claimants alleged that security personnel working for HudBay's former wholly-owned subsidiaries, allegedly under the control and supervision of HudBay, violated human rights. Among other alleged violations were the killing of a community leader, a shooting, and gang rapes in the vicinity of the 
proposed mine (Choc v. Hudbay Minerals Inc. 2013). While the rapes were committed in 2007, before HudBay acquired the project from another Canadian company in 2008, the killing and shooting allegedly occurred in 2009. Civil litigation remains pending. Meanwhile, in 2021, the mine's former security chief (also formerly a lieutenant general in Guatemala's army) pled guilty in a criminal case to murdering the community leader and shooting another man who was left paralyzed (Waddell Phillips Professional Corporation 2021).

Zambia. In 2019, the United Kingdom Supreme Court permitted a civil suit brought by more than 2,500 Zambians to proceed in London against a British company and its Zambian subsidiary for leaks of acidic material. It also alleged that the company knowingly discharged toxic metals above legal limits into river waters near a copper mine in Zambia (Vedanta Resources PLC $v$. Lungowe et al. 2019). According to the summary by the Court of Appeals, the claimants alleged that they relied on the waterways "as 'their primary source of clean water for drinking, bathing, cooking, cleaning and other domestic and recreational purposes.' It is said that the waterways irrigate crops and sustain livestock [and] are a source of fresh fish and that, in consequence, the waterways are 'of critical importance to [the claimants'] livelihoods and their physical, economic and social wellbeing'" (Lungowe et al. v. Vedanta Resources PLC and Konkola Copper Mines PLC2017). In 2021 the case was settled for an undisclosed sum (Leigh Day 2021).

\section{Mining and Laudato Si'}

What is the stance of Catholic social teaching toward such alleged abuses? This section considers how the children of God should treat our common home-the earth—as set forth in Pope Francis's 2015 encyclical Laudato $\mathrm{Si}^{\prime}$. Aspects of its teaching relate to the impacts of mining on human rights, the environment, and peace, and it calls for a deeper change of the culture and values that underpin problems associated with mining. Laudato Si' teaches that abuse of our planetary home is not an accident but has "ethical and spiritual roots" (\$9). It reflects anthropocentrism, individual and societal selfishness, and the myths of markets and technology as saviors. We indulge "the notion that there are no indisputable truths to guide our lives, and hence human freedom is limitless" (\$6). We demand rights without corresponding responsibilities. Such a culture is prone to promote lucrative mining without the corresponding human rights and environmental safeguards, genuine community consultation, or respect for communally owned indigenous land. If buyers demand minerals regardless of the real end use value, the market rules. If environmental protection is needed, mining companies either downplay the problem or look to technological solutions, even if they merely mitigate the damage or postpone the day of reckoning. Laudato Si' diagnoses the cultural maladies more specifically. 
Self-centeredness. Modern culture is beset by "rampant individualism," a "self-centered culture of instant gratification," and a short-term mindset $(\$ 161,181)$. Closely related is an egoistic attitude that we can plunder Sister Earth at will. In contrast, the creation accounts of the Bible leave "no place for a tyrannical anthropocentrism unconcerned for other creatures" (\$68). Francis observes, “Once we lose our humility and become enthralled with the possibility of limitless mastery over everything, we inevitably end up harming society and the environment" (\$224).

Technology. This misconception is what allows for the "technocratic paradigm" that operates by prioritizing control over external objects $(\$ 106)$. It lures us into accepting the idea that technology and ingenuity can accomplish unlimited growth, but it is "based on the lie that there is an infinite supply of the earth's goods, and this leads to the planet being squeezed dry beyond every limit." The mining industry is not specifically named here, but falls clearly within the purview of Francis's concerns.

Technology works wonders in medicine and science. In the market, however, the technocratic paradigm leads to a "reductionism which affects every aspect of human and social life," and its products are "not neutral, for they create a framework which ends up conditioning lifestyles and shaping social possibilities along the lines dictated by the interests of certain powerful groups" (\$107). The tendency is for the economy to accept "every advance in technology with a view to profit, without concern for its potentially negative impact on human beings" (\$109).

Markets. Economic interests such as mining enterprises can trump the common good $(\$ 54)$. While it is supposed to efficiently allocate resources, the market often assigns a value to products that might not reflect their real worth and that can lead to overproduction, which negatively impacts the environment and regional economies. Francis rejects "a magical conception of the market" $(\$ 190)$. The point is not to stifle progress, but to define it in ways other than profit and economic growth. Economic development which does not "respect and promote human rights-personal and social, economic and political, including the rights of nations and of peoples-would not be really worthy of man" (\$93). Therefore, decreased growth might be justified in some parts of the world if it means better protection of the environment, traditional cultures, human rights, and peace $(\$ 193)$. This is not saying that mining companies or other growth-focused multinational businesses are inherently evil. "Business is a noble vocation, directed to producing wealth and improving our world" $(\$ 129)$. Mining creates jobs and gives the world materials. Despite those real benefits, accepting decreased growth in the mining sector in some cases could be an antidote to the technocratic paradigm and a market that makes growth and profit goals unto themselves at the expense of other, more important, values.

Environment. The well-being of the environment is one of those values $(\$ 23-26)$. At least three specific environmental problems addressed in Laudato Si' relate directly to mining: waste and our "throwaway culture," 
climate change, and water poverty. The victims of these problems are disproportionately in the Global South. That imbalance is connected to the "disproportionate use of natural resources by certain countries [in the Global North] over long periods of time" (\$51). A "throwaway culture" leads to wasteful over-consumption, which worsens climate change and yields more demand for mined resources from the Global South, threatening water sources with pollution and creating greater climate vulnerability in areas where the mining occurs $(\$ 20-22)$.

A true ecological approach, Pope Francis teaches, "always becomes a social approach; it must integrate questions of justice in debates on the environment, so as to hear both the cry of the earth and the cry of the poor" $(\$ 49)$. This social approach is evident in the church's insistence that, while a right to private property is important, there is always a "social mortgage on all private property" (\$93). And the natural environment affected by mining is not private property, but a "collective good, the patrimony of all humanity and the responsibility of everyone" $(\$ 95)$. The same cultural and ethical problems that underlie climate change underlie poverty. Similarly, mining not only harms the environment but sometimes exhausts resources on which communities depend, undermines social structures which shape communal identity, and destroys sacred spaces $(\$ 146)$. We are not faced, then, with "two separate crises, one environmental and one social, but rather with one complex crisis which is both social and environmental," and which demands "an integrated approach to combating poverty, restoring dignity to the excluded, and at the same time protecting nature" $(\$ 139)$.

Certain questions should be asked of any proposed venture (including a mine) to discern whether it will contribute to "genuine integral development. What will it accomplish? Why? Where? When? How? For whom? What are the risks? What are the costs? Who will pay these costs and how?” (\$185). Francis also specifically insists that environmental impact assessments should come, not after business plans are already made, but as part of the decision-making process from the beginning. Consensus should be sought among the different stakeholders, "who can offer a variety of approaches, solutions and alternatives," and the local population should have a "special place at the table" (\$ 183). Assessments should be transparent enough and honest enough to allow those populations to make truly informed decisions $(\mathbb{\$} 184)$.

The need to act is urgent. "The pace of consumption, waste and environmental change has so stretched the planet's capacity that our contemporary lifestyle, unsustainable as it is, can only precipitate catastrophes" $(\$ 161)$. Sustainable development is a basic question of justice and "intergenerational solidarity" $(\$ 159)$. Uncertainty cannot be permitted to paralyze action. Laudato $S i$ invokes the precautionary principle, enunciated by the 1992 Rio Declaration of the UN Conference on Environment and Development: "where there are threats of serious or irreversible damage, 


\section{Douglass Cassel}

lack of full scientific certainty shall not be used as a pretext for postponing cost-effective measures" to protect the environment (UNGA 1992).

Peace. A spiritual resource for ushering in the kind of cultural reform Francis describes is the cultivation of peace. St. Francis understood, as his namesake observes, "just how inseparable the bond is between concern for nature, justice for the poor, commitment to society, and interior peace" (Francis 2015, \$10). Laudato Si' explains that inner peace is essential to the conversion that is needed for real cultural change along the lines of integral ecology $(\$ 225)$. Inner peace recognizes that "less is more" $(\$ 222)$. However, mining places exterior or communal peace at risk. As illustrated by the above case of alleged abuses in Guatemala, mining may not only disturb individual and social tranquility, but also often ignites violence or even fuels armed conflict. And indeed, Francis clearly includes concern for peace in the matrix of integral goods that are threatened by ecological indifference and preoccupation with profit over justice and human dignity $(\$ 82,92)$.

A Way Forward. The cultural values and norms highlighted above suggest that "bold cultural revolution" is needed $(\$ 114)$. While appreciating material progress, we must recover values "swept away by our unrestrained delusions of grandeur." We must not seek to shape the earth solely to our own ends, but instead engage in "responsible stewardship" (\$116). We cannot renew our relationship with nature "without a renewal of humanity itself. There can be no ecology without an adequate anthropology" (\$118). The challenge is to "to bring the whole human family together to seek a sustainable and integral development," one sensitive to the suffering imposed by environmental degradation, economic inequities, and violence on the poor $(\$ 13)$.

Nor can cultural change do it alone. For changes in culture to succeed, they must be accompanied by changes in laws $(\$ 53)$. But the reverse is also true. If the laws are to bring about "significant, long-lasting effects, the majority of the members of society must be adequately motivated to accept them, and personally transformed to respond" $(\$ 211)$. Moreover, even well-framed laws governing the mining industry are often ineffective because much of the world's mining takes place in nations with weak institutions, little respect for the rule of law, and citizens who lack political power $(\$ 142)$.

But national laws and political power are not enough. Individual countries often face a power imbalance in confronting huge, multinational mining companies. For example, the Anglo-Swiss mining giant Glencore had revenues in 2019 of $\$ 215$ billion (Mining Technology 2020)—more than the entire GDPs of mining nations such as Bolivia (\$41 billion), Guatemala ( $\$ 77$ billion), or Zambia ( $\$ 23$ billion) (World Bank n.d.). It follows that "[e]nforceable international agreements are urgently needed... to impose obligations and prevent unacceptable actions, for example, when powerful companies or countries ... offshore polluting industries in other countries" (Francis 2015, $\$ 173$ ). 


\section{International human rights norms}

International human rights norms do not presuppose a belief in the divine. They proclaim freedom, not only of religion, but also of conscience-which includes the right not to believe in any divine power (UNGA 1966a, art. 18.1). They do not presume to denounce the materialistic values of contemporary culture, or to challenge the prevalent paradigm of unending technological progress and economic growth. They are the product, not of a unified epistemology, but of negotiated—or feigned—agreement on fundamental rights among disparate cultures and political systems.

While they do not join Catholic social teaching, or indeed any religion, in reaching for the heavenly, international human rights norms are consistent, as far as they go, with Catholic social teaching. They are centered on human dignity (UNGA 1948, art. 1). They ask states to respect not only civil and political rights (UNGA 1966a), but also economic, social, and cultural rights (UNGA 1966b). They consecrate workers' rights to decent wages and hours, working conditions, and to organize and bargain collectively (UNGA 1948, art. 23; International Labour Organization 2010). They recognize that the right to private property can be subordinated to public purpose (Organization of American States 2011, art. 21.1), albeit with due monetary compensation (art. 21.2). They include the human right to a decent environment (UNGA 2018, $\$ 1$; African Union 1981, art. 24; Organization of American States 1999, art. 11.1; European Union 2012, art. 37; Association of Southeast Asian Nations 2013, art. 28.f; Community of Latin American and Caribbean States 2018). Some of their instruments embrace the precautionary principle (Organisation for Economic Co-operation and Development 2011, art. VI.4). They call for meaningful consultation with affected communities (UN Office of the High Commissioner for Human Rights 2011, principle 18.a) and, for indigenous peoples, "free, prior and informed consent" before initiating major development projects (UNGA 2007, art. 10, 11.2, 19, 29.2, 32.2). International norms include a right to development, albeit vaguely defined and largely unenforceable (UNGA 1986).

For mining-and indeed for business generally-the central instrument is the UN Guiding Principles on Business and Human Rights (UNGPs), adopted by consensus of the UN Human Rights Council in 2011, and now widely incorporated or endorsed by other international and regional instruments, as well as by industry and company policies, and the church (UN Office of the High Commissioner for Human Rights 2011).

The UNGPs rest on three pillars. Pillar I is addressed to states. It reaffirms that they have a "duty to protect" human rights from infringement by third parties, including business (principle 1). This largely restates and particularizes legal duties of states under existing international human rights law. 


\section{Douglass Cassel}

Pillar II addresses business. It recognizes that business has a "responsibility to respect" human rights (principle 11), which is less demanding than the state's “duty to protect." The responsibility is both negative and positive. Negatively, companies should not violate human rights. Positively, they should adopt formal human rights policies (principle 15, 16); exercise due diligence to anticipate and avoid adverse human rights impacts which they cause or contribute to through their own activities (principle 13,17); use their leverage to seek to prevent or mitigate adverse human rights impacts arising from their business relationships (principle 13); engage in meaningful consultation with potentially affected groups and other stakeholders (principle 18); monitor and report on the human rights impacts of their activities on a regular basis (principle 20,21); and address such impacts when they occur (principle 15, 19). Even if the responsibility of business to respect human rights is not (yet) a legal duty, neither is it purely voluntary. It reflects societal expectations of business, which are now articulated, not only in the UNGPs, but in the many governmental and business documents which adopt it (UNGA 2008, $\mathbb{5 4}$ ).

Pillar III is addressed to both states and business. It recognizes the right of victims to remedies for business-related human rights abuses. States have a duty to provide both judicial and non-judicial remedies (UN Office of the High Commissioner for Human Rights 2011, principle 25-28). Where business identifies that it has caused or contributed to an adverse impact, it has a responsibility to provide or cooperate in remediation through legitimate processes (principle 22). Business also has a responsibility to provide non-judicial remedies through genuine, rights-compatible grievance procedures (principle 29-31).

The UNGPs do not call on companies to love their neighbors or renounce materialism. They nonetheless add a welcome degree of practical effectiveness and specificity to Catholic social teaching on human rights and ecology as applied to mining. The principles themselves are relatively precise. For example, principle 16 provides not only that a company should have a "policy commitment" to respect human rights, but more specifically that the policy should: be approved at the most senior level; be informed by expertise; state the company's human rights expectations of personnel, business partners and other parties directly linked to its activities; be publicly available and communicated internally and externally; and be reflected in operational policies and procedures necessary to embed it throughout the company.

The UNGPs lend themselves to implementation by business generally and the mining industry in particular. In 2018 the International Council of Metals and Mining (ICMM), representing 27 of the world's largest mining companies, announced that it had become the first mining industry body to commit its members to implement the UNGPs. The principles are thus to be put in practice by ICMM member companies, which together cover over a quarter of all mined commodities by value. 
The UNGPs also signal the business responsibility to respect an array of other international human rights instruments, most of which were originally directed largely or only to states. Principle 12 calls on business to respect the International Covenant on Civil and Political Rights; the International Covenant on Economic, Social and Cultural Rights; the Universal Declaration of Human Rights; and the International Labour Organization's Declaration on Fundamental Principles and Rights at Work. Together these instruments cover a broad spectrum of human rights. Even so, for particular contexts such as mining, principle 12 goes further, recognizing that "[a]dditional standards may be applicable in particular situations, such as the UN Declaration on the Rights of Indigenous Peoples.” Among other provisions, the UN Declaration requires that free, prior, and informed consent of indigenous peoples be sought before mining on their lands or using their waters or other resources (UNGA 2007, e.g., art. 32.2).

Formally, the Declaration is not legally binding. Nonetheless, it can be used to assess whether business meets its responsibility to respect human rights. It also informs interpretation of treaties which are legally binding on states. For example, International Labour Organization Convention 169 requires "free and informed consent" before indigenous peoples are relocated (International Labour Organization 1989, art. 16.2). Although joined by only 23 states, they include such important mining countries as Bolivia, Brazil, Chile, Mexico, and Peru. ${ }^{2}$

Regional human rights treaties have also been interpreted to require free, prior, and informed consent. In the Americas, nearly all Latin American countries are parties to the American Convention on Human Rights. The Convention has been interpreted by the Inter-American Court of Human Rights (2012, \$177-211) to mandate free, prior and informed consultation with indigenous peoples. Moreover, in cases involving major impact projects within indigenous territory, "the State has a duty, not only to consult with [them]..., but also to obtain their free, prior, and informed consent, according to their customs and traditions" (Inter-American Court of Human Rights 2007, \$134). In Africa, the African Court of Human and Peoples' Rights $(2017, \mathbb{\$} 131)$ has held that States have at least a duty of "prior consultation" (and perhaps consent) before expelling an indigenous people from its land. These injunctions to consult versus obtain consent reflect varying legal interpretations of the force such regulations hold. The above sources refer those regulations to states, but the UNGPs make companies, including mining companies, responsible to use the leverage they may have to try to ensure that genuine consultation takes place and that, at minimum, free, prior, and informed consent is sought.

The foregoing discussion of norms from the UNGPs that are applicable to mining is not exhaustive. Still, it provides starting points for practitioners of Catholic peacebuilding who wish to bring widely supported secular norms to bear in the defense of human dignity, planetary survival, the common good, and peace. 


\section{International norms on peace}

With relatively few but nonetheless important exceptions, ${ }^{3}$ international law does not generally address the kind of interior peace of which St. Francis wrote, which is likely to be damaged by the kinds of human rights and environmental abuses associated with mining. International law mainly addresses the right to external peace-the absence of armed conflict. The UN General Assembly's Declaration on the Right to Peace provides, "Everyone has the right to enjoy peace such that all human rights are promoted and protected and development is fully realized" (UNGA 2016, art. 1). The human rights provisions of the Declaration address not only international wars and internal armed conflicts, but arguably also civil disturbances, such as those arising from mining disputes (art. 2). By themselves, this and earlier UN declarations on peace are not legally binding. However, they can be politically and diplomatically influential. They may also be used judicially to interpret treaties (such as the UN Charter).

The UNGPs are also not legally binding but provide guidance to business, including mining companies, operating in conflict zones:

'[C]onflict-affected areas' may increase the risks of enterprises being complicit in gross human rights abuses committed by other actors (security forces, for example). Business enterprises should treat this risk as a legal compliance issue, given the expanding web of potential corporate legal liability arising from extraterritorial civil claims, and from the incorporation of the provisions of the Rome Statute of the International Criminal Court in jurisdictions that provide for corporate criminal responsibility. In addition, corporate directors, officers and employees may be subject to individual liability for acts that amount to gross human rights abuses. In complex contexts such as these, business enterprises should ensure that they do not exacerbate the situation. (UN Office of the High Commissioner for Human Rights 2011, principle 23 commentary)

Aside from these human rights instruments, most international norms on peace in the UN Charter, international humanitarian law, and international criminal law do not usually apply to mining disputes, for two main reasons. First, most international law on resort to war is restricted to wars between nations, which are rarely triggered by mining disputes. ${ }^{4}$ Second, international laws mandating humane conduct of internal armed conflicts between governments and insurgents would apply to conflicts tied to mining only if they involve a high threshold of military organization, discipline, and violence, as with rebel groups in the Democratic Republic of the Congo, though not the riots or sporadic violence typically involved in mining disputes (International Criminal Court 2011, art. 8.2.d). 
However, international law does not ignore communities victimized by violence in mining disputes. International human rights law applies. It protects, for example, the rights to life and bodily integrity, as well as freedoms of speech, association, and peaceful assembly (UNGA 1966a, art. $6,7,10,18,19,22)$. In cases before international human rights bodies, advocates may use the UN Declaration on the Right to Peace "within and between societies," and the UNGPs on risks in conflict zones, to help interpret human rights norms in the context of violent mining disputes.

\section{Combining for peace and the common good}

While Catholic social teaching is more ambitious and aspirational, international human rights norms are more concrete and immediately practical (even if narrower). In addressing mining, Catholics need not choose between the two. The church will not and should not retreat from its commitments inspired by the Gospel. At the same time, as Laudato Si' teaches, the task before us is so immense that Catholics need to reach out to all people of good will to curb the calamities to which mining often contributes.

That means reaching out, beyond even other religious communities, to secular activists, victims of abuses, NGOs, human rights and environmental lawyers, courts, governments, the media-and mining companies, with whom the church has dialogued in recent years (Francis 2019). Outreach is best communicated through language readily understood by others, and by invoking norms they embrace, so long as those norms are consistent with Catholic social teaching. In addressing mining, the Catholic community would be well-advised not to limit itself to Catholic doctrine. The church should endeavor to ensure that its recommendations on mining to governments, business, and society are consistent with, and capture the essentials of, relevant international human rights norms, including but not limited to the widely endorsed UNGPs. Among other things, this means becoming acquainted with the content of the UNGPs. In general, the state's "duty to protect" and the business's "responsibility to respect" human rights (including environmental rights and the right to peace) are eminently consistent with Catholic social teaching. If in any instance the church believes that it must depart from an aspect of the UNGPs, the need for such a departure should be carefully reasoned and publicly articulated. Outreach has practical value. Even if it may not meet all the broad spiritual objectives of the church, it adds social and political heft by uniting the persuasive powers of both religious and secular norms and actors against the power of multinational mining companies. It thereby concretely advances Catholic social principles on human rights, the environment, and peace. The church can and should unite its voice with victims and with those who advocate putting secular norms into practice, as opposed to merely articulating them in empty promises. 
In reaching out, the church can bring to bear its broader perspective. For example, cost-benefit analyses of mining projects should not be limited to impacts in the local community, but should be expanded to take into account the social utility, or lack thereof, of the end for which the mining is undertaken. It is one thing to expose local residents to some degree of risk in order to mine precious metals essential for computer networks in hospitals. It is quite another to ask them to sacrifice in order to mine gold or silver for luxury trinkets. If communities near a mine are to be asked to face some degree of risk, it should at the very least be for morally justifiable ends. This point, not addressed by secular international human rights norms, is a spiritual truth taught by Laudato $S i$ ' and its critique of mining in light of larger cultural maladies of consumerism, materialism, and waste.

However, assessing end use may be difficult in practice. If a mineral is mined for sale on the world market, there may be no way in advance to know or to value its eventual end use. It may eventually be sold as jewelry or used for heart monitors. Or a mining company may know the end uses but refuse to disclose them. Or there is the conundrum of how to assess mining which damages the environment when the minerals are to be used for renewable energy technology to mitigate climate change, as discussed by Holden and Montevecchio later in this book. To overcome such practical obstacles, the church could learn both positive and negative lessons from secular norms and procedures on mining due diligence (European Parliament and the Council of the European Union 2017), transparency (Extractive Industries Transparency Initiative n.d.), disclosure (US Congress 2010, sec. 1502.b), reporting (UK Parliament 2015, sec. 52), and certifications (Kimberley Process n.d.). The church does not need to reinvent wheels. Secular experience may either point the way to solutions, signal where they are elusive, or clarify when certain approaches are unworkable. On the other hand, without advocacy by the church and others of broader vision, international and national laws might continue to permit mines to be licensed without regard to end uses. Just as Catholic social teaching can learn from international human rights law, so too international law can learn from Catholic principles.

Laudato $\mathrm{Si}^{\prime}$ further teaches that necessary cultural change cannot fully succeed without legal change. This means that the church should learn about existing national mining laws and advocate reforms. In Guatemala in the early 2000s, for example, the church played a key role in developing a draft reform of the mining law (Holden and Jacobson 2009). Although the draft was not adopted by the country's lawmakers, the church stood-and was seen to stand-with the people and on the right side of history.

Elsewhere church campaigns on mining may meet with greater success, as seen in two cases from this book. As outlined by Andrés McKinley, in El Salvador church support was important to a ban on mining, which the government later successfully defended in an international arbitration brought by mining companies (Palumbo and Malkin 2017; Malkin 2016). The ban on mining "marked the culmination of a multi-year campaign in 
which the archbishop of San Salvador and the Jesuit-run Central American University played a major role" (Palumbo 2017). And in the chapter on Peru, José Bayardo Chata Pacoricona describes several court successes arguing against mining development and active pursuit of varied legal actions on behalf of indigenous and other marginalized communities.

As the contrasting outcomes in the neighboring countries of El Salvador and Guatemala suggest, national laws alone may not always prevail over the wealth and power of large mining companies. Since the operations of multinational mining enterprises extend beyond the reach of any one nation it is important, as recognized by Laudato Si, to develop global regulatory norms and institutions with the power to impose sanctions. For example, without endorsing any particular text, the Holy See has repeatedly endorsed the concept of a legally binding treaty on business and human rights to regulate transnational business, including mining companies. Citing Laudato Si, the Holy See in 2017 told the UN intergovernmental group working on a proposed treaty that:

[I]t is important to recognize that there are good reasons why international law might devote specific attention to transnational corporations and in particular their accountability for human rights abuses. An international legal instrument has the potential to make corporations criminally, civilly, and administratively liable, while guaranteeing the protection of human rights, providing access to judicial remedy, and adding an important tool for accountability. (Jurkovič 2017, n.p.)

These are examples of how the church can work on mining issues with other faith and secular communities: through outreach, in campaigns to improve national laws, and in shaping and invoking international laws and institutions. The church must of course continue its indispensable spiritual and social teaching. However, if the church is to overcome injustice in mining, a bridge to persons of goodwill can be built by learning the language and using the norms of international human rights. Neither Catholic social teaching nor international norms suffice by themselves to shield human rights, the environment, and peace, from the adverse impacts of mining. What the church needs is an approach grounded in the Gospel but also informed by international human rights law.

\section{Notes}

1 Compare, for example, Green America (n.d.) with Totty (2008).

2 Information on ratifications of the Indigenous and Tribal Peoples' Convention can be found at https://www.ilo.org/dyn/normlex/en/f?p=NORMLEXPUB:11300::: NO:11300:P11300_INSTRUMENT_ID:312314:NO.

3 For example, mental pain and suffering may be included as an element of monetary reparations for gross violations of human rights (see Inter-American Court of Human Rights 2003, \$260-66; International Criminal Court 2011, art 7.1.k). 
4 One exception is armed conflict between insurgent groups supported by Rwanda in the Democratic Republic of the Congo (see Schneider 2012).

\section{References}

African Court on Human and People's Rights. 2017. African Commission on Human and Peoples' Rights v. Kenya. Judgment of May 26, 2017. https:// www.escr-net.org/caselaw/2017/african-commission-human-and-peoples-rightsv-republic-kenya-acthpr-application-no.

African Union. 1981. African Charter on Human and Peoples' Rights. OAU Doc. CAB/LEG/67/3. June, 1981. https://www.achpr.org/legalinstruments/detail?id=49.

Association of Southeast Asian Nations. 2013. ASEAN Human Rights Declaration. https://www.asean.org/storage/images/ASEAN_RTK_2014/6_AHRD_Booklet.pdf.

Bnamericas. 2021. "Glencore files new arbitration claims against Colombia." June 3, 2021. https://www.bnamericas.com/en/news/glencore-files-new-arbitrationclaims-against-colombia.

Brown, Catherine. 2016. "State-Owned Copper Mining: Climate Change vs. Country Development.” Harvard Business School. November 4, 2016. https:// digital.hbs.edu/platform-rctom/ submission/state-owned-copper-mining-climatechange-vs-country-development/.

Choc v. Hudbay Minerals Inc. 2013. ONSC 1414. Ontario. July 22, 2013.

Community of Latin American and Caribbean States. 2018. Regional Agreement on Access to Information, Public Participation and Justice in Environmental Matters in Latin America and the Caribbean (Escazú Agreement). March 4, 2018. https://repositorio.cepal.org/bitstream/handle/11362/43583/1/S1800428_ en.pdf.

DeJusticia and Business and Human Rights Resource Centre. 2015. Digging Deeper: The Human Rights Impacts of Coal in the Global South. Edited by Krizna Gomez and Gregory Regaignon. Creative Commons: November, 2015. http://media.wix.com/ugd/c04a21_3e6e58c1b5804082bf31ac72699d0c53.pdf.

European Parliament and the Council of the European Union. 2017. "Laying Down Supply Chain Due Diligence Obligations for Union Importers of Tin, Tantalum and Tungsten, Their Ores, and Gold Originating from Conflict-Affected and High-Risk Areas." Regulation (EU) 2017/821. May 17, 2017. https://eurlex.europa.eu/legal-content/EN/TXT/?uri=CELEX\%3A32017R0821.

European Union. 2012. Charter of Fundamental Rights of the European Union. 2012/C 326/02. October 26, 2012. https://eurlex.europa.eu/eli/treaty/char_ 2012/oj.

Extractive Industries Transparency Initiative. n.d. "Who We Are.” Accessed March 9, 2021. https://eiti.org/who-we-are.

Francis. 2015. Laudato Si'. http://www.vatican.va/content/francesco/en/encyclicals/ documents/papa-francesco_20150524_enciclica-laudato-si.html.

Francis. 2019. "Address to Participants at the Meeting Promoted by the Dicastery for Promoting Integral Human Development on the Mining Industry.” May 3, 2019. http://www.vatican.va/content/francesco/en/speeches/2019/may/documents/papafrancesco_20190503_incontro-industria-mineraria.html.

Glendon, Mary Ann. 1998. "Knowing the Universal Declaration of Human Rights." Notre Dame Law Review 73, no. 5: 1153-1190. 
GLAN (Global Legal Action Network). 2021. Non-Compliance with the OECD Guidelines for Multinational Enterprises. January 21, 2021. https://media.businesshumanrights.org/media/documents/Full_text_complaint_before_OECD_by_GLAN. pdf.

Green America. n.d. "10 Reasons to Oppose Nuclear Energy.” Accessed March 8, 2021. https://www.greenamerica.org/fight-dirty-energy/amazon-build-cleanercloud/10-reasons-oppose-nuclear-energy.

Greenpeace Australia Pacific. 2017. "Steeling the Future: The Truth Behind Australian Metallurgical Coal Exports.” June 2017. https:/www.greenpeace.org.au/wp/wpcontent/uploads/2017/06/280517-GPAP-Steeling-the-Future-Report-LR.pdf.

Griffin, Oliver, and Luis Jaime Acosta. 2020. "Colombia’s Mining Future Tied to Metals Not Coal, Minister Says.” Reuters, October 2, 2020. https://www.reuters.com/ article/us-colombia-energy/colombias-mining-future-tied-to-metals-not-coal-ministersays-idUSKBN26N2HK.

Heath, Nick. 2014. "How Conflict Minerals Funded a War That Killed Millions, and Why Tech Giants Are Finally Cleaning Up Their Act." Tech Republic, March 31, 2014. https://www.techrepublic.com/article/how-conflict-minerals-funded-awar-that-killed-millions/.

Holden, William N., and R. Daniel Jacobson. 2009. "Ecclesial Opposition to Nonferrous Mining in Guatemala: Neoliberalism Meets the Church of the Poor in a Shattered Society." The Canadian Geographer 53, no. 2: 145-164.

ICMM (International Council of Mining and Metals). 2018. "ICMM First Industry Body to Commit to UN Guiding Principles on Business and Human Rights." November 26, 2018. https://www.icmm.com/en-gb/news/2018/unhuman-rights-pr.

Inter-American Court of Human Rights. 2003. Case of Myrna Mack Chang $v$. Guatemala. Judgment of November 25, 2003. https://www.corteidh.or.cr/docs/ casos/articulos/seriec_101_ing.pdf.

Inter-American Court of Human Rights. 2007. Case of the Saramaka People $v$. Suriname. Judgment of November 28, 2007. https://www.corteidh.or.cr/docs/ casos/articulos/seriec_172_ing.pdf.

Inter-American Court of Human Rights. 2012. Case of the Kichwa Indigenous People of Sarayaku v. Ecuador. Judgment of June 27, 2012. https://corteidh.or.cr/ docs/casos/articulos/seriec_245_ing.pdf.

International Criminal Court. 2011. Rome Statute of the International Criminal Court. https://www.icc-cpi.int/resource-library/documents/rs-eng.pdf.

International Energy Agency. 2020. Coal 2020: Analysis and Forecast to 2025, Fuel Report. December 2020. https://www.iea.org/reports/coal-2020.

International Labour Organization. 1989. Indigenous and Tribal Peoples' Convention. C169. https://www.ilo.org/dyn/normlex/en/f?p=NORMLEXPUB:12100:0::NO:: P12100_ILO_CODE:C169.

International Labour Organization. 2010. Declaration on Fundamental Principles and Rights at Work. June 18, 1998 (revised June 15, 2010). https://www.ilo.org/ declaration/lang--en/index.htm.

Jurkovič, Ivan. 2017. "Statement by Archbishop Ivan Jurkovič, Permanent Observer of the Holy See to the UN and Other International Organizations in Geneva." October 25, 2017. https://www.ohchr.org/Documents/HRBodies/HRCouncil/ WGTransCorp/Session3/OralInterventions/HolySee-Subject5.LegalLiability.pdf. 


\section{Douglass Cassel}

Kimberly Process. n.d. "What is the Kimberly Process?” Accessed March 9, 2021. https://www.kimberleyprocess.com/en/what-kp.

King, Hobart M. n.d. "Blood Diamonds-Conflict Diamonds-What is the Kimberley Process?” Accessed March 8, 2021. https://geology.com/articles/ blood-diamonds.shtml.

Leigh Day. 2021. "Legal Claim by More Than 2,500 Zambian Villagers in a Case Against Vedanta Resources Limited.” January 19, 2021. https:/www.leighday.co.uk/ latest-updates/news/2021-news/legal-claim-by-more-than-2-500-zambian-villagers-ina-case-against-vedanta-resources-limited/.

Lungowe et al. v. Vedanta Resources PLC and Konkola Copper Mines PLC. 2017. EWCA Civ 1528. November 2017.

Malkin, Elizabeth. 2016. "El Salvador Wins Dispute Over Denying a Mining Permit." New York Times, October 14, 2016. https://www.nytimes.com/2016/ 10/15/world/americas/salvador-mining-dispute.html.

Mining Technology. 2020. “Top Ten Metals and Mining Companies in 2020." Updated October 12, 2020. https:/www.mining-technology.com/features/topten-metals-and-mining-companies-in-2020/.

Organisation for Economic Co-operation and Development. 2011. OECD Guidelines for Multinational Enterprises. http://www.oecd.org/daf/inv/mne/48004323.pdf.

Organization of American States. 1999. Additional Protocol to the American Convention on Human Rights in the Area of Economic, Social and Cultural Rights. A-52. November 16, 1999. https://www.refworld.org/docid/3ae6b3 b90.html.

Organization of American States. 2011. American Convention on Human Rights. https://www.oas.org/dil/treaties_b-32_american_convention_on_human_ rights.pdf.

Palumbo, Gene. 2017. "Spurred by Catholic Leaders, El Salvador Becomes First Nation to Ban Mining." America, April 3, 2017. https://www.americamagazine. org/politics-society/2017/04/03/spurred-catholic-leaders-el-salvador-becomes-firstnation-ban-mining.

Palumbo, Gene, and Elizabeth Malkin. 2017. "El Salvador, Prizing Water Over Gold, Bans All Metal Mining." New York Times. March 29, 2017. https:// www.nytimes.com/2017/03/29/world/americas/el-salvador-prizing-water-overgold-bans-all-metal-mining.html.

Pooler, Michael. 2019. "Cleaning Up Steel Is Key to Tackling Climate Change.” Financial Times, January 1, 2019. https://www.ft.com/content/3bcbcb60-037f11e9-99df-6183d3002ee1.

Reuters. 2021. "Coal Miner Cerrejon Says Reached Deal With Indigenous Community on Environment, Health.” February 26, 2021. https://www.reuters. $\mathrm{com} /$ article/us-cerrejon-colombia/coal-miner-cerrejon-says-reached-deal-with-indigenous-community-on-environment-health-idUSKBN2AQ2W7.

Schneider, Mark. 2012. "Examining the Role of Rwanda in the DRC Insurgency." Testimony before the U.S. House Committee on Foreign Affairs Subcommittee, September 19, 2012. https://www.crisisgroup.org/africa/central-africa/democraticrepublic-congo/examining-role-rwanda-drc-insurgency.

Sepanek, Eric. 2012. “Top 6 Common Uses for Gold.” Scottsdale Bullion \& Coin. May 30, 2012. https://www.sbcgold.com/blog/top-6-common-uses-for-gold/. 
Tomasi, Silvano. 2014. "Statement by Archbishop Silvano M. Tomasi, Permanent Observer of the Holy See to the United Nations and Other Specialized Agencies in Geneva.” June 11, 2014. http://www.vatican.va/roman_curia/secretariat_state/ 2014/documents/rc-seg-st-20140611_tomasi-diritti-umani_en.html.

Totty, Michael. 2008. "The Case For and Against Nuclear Power." Wall Street Journal, June 30, 2008. https://www.wsj.com/articles/SB121432182593500119.

UK Parliament. 2015. UK Modern Slavery Act 2015. C. 30. March 26, 2015. https://www.legislation.gov.uk/ukpga/2015/30/contents/enacted.

UNGA (UN General Assembly). 1948. Universal Declaration of Human Rights. A/RES/217(III). December 10, 1948. https://www.un.org/en/development/desa/ population/migration/generalassembly/docs/globalcompact/A_RES_217(III).pdf.

UNGA (UN General Assembly). 1966a. International Covenant on Civil and Political Rights. A/RES/2200A(XXI). December 16, 1966. https://www.un.org/ en/development/desa/population/migration/generalassembly/docs/globalcompact/ A_RES_2200A(XXI)_civil.pdf.

UNGA (UN General Assembly). 1966b. International Covenant on Economic, Social and Cultural Rights, A/RES/2200A(XXI). December 16, 1966. https:// www.un.org/en/development/desa/population/migration/generalassembly/docs/ globalcompact/A_RES_2200A(XXI)_economic.pdf.

UNGA (UN General Assembly). 1986. UN Declaration on the Right to Development. A/RES/41/128. December 4, 1986. https://undocs.org/A/RES/41/128.

UNGA (UN General Assembly). 1992. "Rio Declaration on Environment and Development.” A/CONF.151/26 (Vol. I). August 12, 1992. https://www.un.org/ en/development/desa/population/migration/generalassembly/docs/globalcompact/ A_CONF.151_26_Vol.I_Declaration.pdf.

UNGA (UN General Assembly). 2007. UN Declaration on the Rights of Indigenous Peoples. A/RES/61/295. September 13, 2007. https://undocs.org/A/RES/61/295.

UNGA (UN General Assembly). 2008. Report of the Special Representative of the Secretary-General on the Issue of Human Rights and Transnational Corporations and Other Business Enterprises, John Ruggie. Human Rights Council Session 8. A/HRC/8/5. April 7, 2008. https://www.undocs.org/A/HRC/8/5.

UNGA (UN General Assembly). 2011a. Human Rights and Transnational Corporations and Other Business Enterprises. Human Rights Council Session 17. A/HRC/RES17/4. June 16, 2011. https://documents-dds-ny.un.org/doc/ RESOLUTION/GEN/G11/144/71/PDF/G1114471.pdf? OpenElement.

UNGA (UN General Assembly). 2011b. Report of the Special Representative of the Secretary-General on the Issue of Human Rights and Transnational Corporations and Other Business Enterprises, John Ruggie. Human Rights Council Session 17. A/HRC/17/31. March 21, 2011. https://undocs.org/en/A/HRC/17/31.

UNGA (UN General Assembly). 2016. UN Declaration on the Right of Peoples to Peace. A/RES/71/189. December 19, 2016. https://undocs.org/en/A/RES/ $71 / 189$.

UNGA (UN General Assembly). 2018. Human Rights and the Environment. Human Rights Council Session 37. A/HRC/RES/37/8. March 22, 2018. https:// undocs.org/en/A/HRC/RES/37/8.

UN Office of the High Commissioner for Human Rights. 2011. UN Guiding Principles on Business and Human Rights. https://www.ohchr.org/Documents/ Publications/GuidingPrinciplesBusinessHR_EN.pdf. 


\section{Douglass Cassel}

US Congress, House. 2010. Dodd-Frank Wall Street Reform and Consumer Protection Act. HR 4173, 111th Congress. July 21, 2010. https://www.congress. gov/bill/111th-congress/house-bill/4173/text.

UITA (US International Trade Administration). 2019a. "Bolivia-Mining.” In Bolivia Country Commercial Guide. Last updated July 12, 2019. https://www.export.gov/ apex/article2?id=Bolivia-Mining.

UITA (US International Trade Administration). 2019b. "Mexico-M. Mining and Minerals." In Mexico Country Commercial Guide. Last updated October 17, 2019. https://www.export.gov/apex/article2?id=Mexico-Mining-and-Minerals.

UITA (US International Trade Administration). 2020. "Mining Equipment and Machinery.” In Peru Country Commercial Guide. Last updated October 11, 2020. https://www.trade.gov/country-commercial-guides/peru-mining-equipment-andmachinery.

UITA (US International Trade Administration). “Mining.” 2021. In Chile Country Commercial Guide. Last updated January 16, 2021. https://www.trade.gov/ knowledge-product/chile-mining-and-minerals.

Vedanta Resources PLC v. Lungowe et al. 2019. UKSC 2017/0185. April 10, 2019. Waddell Phillips Professional Corporation.2021. "Head of Security at Hudbay Minerals' Former Guatemalan Mine Pleads Guilty to Killing Community Leader and Shooting Bystander." YahooFinance, January 6, 2021. https://ca.finance.yahoo.com/ news/head-security-hudbay-minerals-former-215000236.html.

The World Bank. n.d. “GDP (current US \$).” Accessed March 8, 2021. https:// data.worldbank.org/indicator/NY.GDP.MKTP.CD.

Wu, Guohua, and Yingnan Li. 2018. "Mining in China: Overview." Thomson Reuters Practical Law, May 1, 2018. https://uk.practicallaw.thomsonreuters.com/ $\mathrm{w}-0111348$ ? transition Type $=$ Default $\&$ contextData $=(\mathrm{sc}$. Default $) \&$ firstPage $=$ true . 